\title{
21. GEOTECHNICAL PROPERTIES OF PLEISTOCENE SEDIMENTS FROM THE NEW JERSEY UPPER CONTINENTAL SLOPE ${ }^{1}$
}

\author{
Peter Blum, ${ }^{2}$ Jianqing $\mathrm{Xu},{ }^{3}$ and Srinivas Donthireddy ${ }^{3}$
}

\begin{abstract}
Consolidation tests on silty mud samples from the Pleistocene upper continental slope at ODP Sites 902 and 903 , off the New Jersey margin, reveal overconsolidation in the uppermost few meters, mostly normal consolidation to a depth of about 80 mbsf, and underconsolidation near $60 \mathrm{mbsf}$ and from 80 to $130 \mathrm{mbsf}$, the maximum depth of investigation. In the underconsolidated section, excess pore pressures are estimated between 100 and $600 \mathrm{kPa}$. Underconsolidated intervals correspond to moderate to vigorous gas escape observed during recovery of the cores. If in situ methane production is the dominant cause of underconsolidation, free gas most likely exists somewhere within those intervals. Underconsolidation also appears to correlate with cyclic intervals of lower void ratio deposited during glacial times. Measured permeability varies only within a narrow range and is of the same one-half order of magnitude for most samples, about $3 \times 10^{-17}$ to $8 \times 10^{-17} \mathrm{~m}^{2}$; only one clayey silt sample is more permeable by almost one order of magnitude. In the absence of significant variations in permeability through the section, sediment texture and composition must be further investigated to explain the observed intervals of underconsolidation and their potential relationships with properties controlled by sea-level changes.
\end{abstract}

\section{INTRODUCTION}

Ocean Drilling Program (ODP) Leg 150 drilled upper continental slope sequences off New Jersey to several hundred meters below seafloor (mbsf) at four sites, with the main objective to date seismic sequence boundaries, relate them to climate change proxies, and study the physical relationships between sediment sequences and sea-level changes (Mountain, Miller, Blum, et al., 1994; Mountain, Miller, and the Leg 150 Shipboard Scientific Party, 1994). We examined the state of consolidation in the Pleistocene sediment sequences at Holes 902D and 903B to estimate the stress history, evaluate the geotechnical significance of methane in recovered cores, and estimate excess pore pressures in the formation. We compared our results with void ratio variations which can be correlated to the isotopic record of past global climate changes.

Sites 902 and 903 are located about $140 \mathrm{~km}$ east-southeast of Barnegat Inlet, in a region of steeply sloping topography (average $3^{\circ}$ ) and numerous slope canyons. Hole $902 \mathrm{D}$ is in $808 \mathrm{~m}$ of water, on the flank and $3.7 \mathrm{~km}$ southwest of the thalweg of "middle Berkeley" canyon (Figs. 1, 2). Hole 903B was drilled $4.4 \mathrm{~km}$ upslope of Site 902, at $446 \mathrm{~m}$ depth and $2.2 \mathrm{~km}$ northeast of the thalweg of upper Carteret Canyon on the northeast flank of "lower Berkeley" canyon (Figs. 1, 2). This slope area is characterized by numerous recent and abandoned, now-buried canyons (e.g., Pratson et al., 1994). Bathymetry and thickness of individual, Pleistocene seismic sequences vary drastically over distances as short as a few hundred meters (Fig. 2). Seismic records are further characterized by many angular unconformities resulting from canyon cutting and filling by mass wasting, gravity flows, and related processes (e.g., Robb et al., 1981; Fig. 2). Near Sites 902 and 903, a Pleistocene unconformity at about 130 to 150 $\mathrm{mbsf}$ ( $185 \mathrm{~ms}$ from the seafloor) is recognized on seismic profiles and in the recovered cores. At Site 902, the unconformity represents the

'Mountain, G.S., Miller, K.G., Blum, P., Poag, C.W., and Twichell, D.C. (Eds.), 1996. Proc. ODP, Sci. Results, 150: College Station, TX (Ocean Drilling Program).

${ }^{2}$ Ocean Drilling Program, 1000 Discovery Drive, Texas A\&M University Research Park, College Station, TX 77845-9547, U.S.A. peter_blum@odp.tamu.edu

${ }^{3}$ Department of Civil Engineering, Texas A\&M University, College Station, TX 77843, U.S.A.

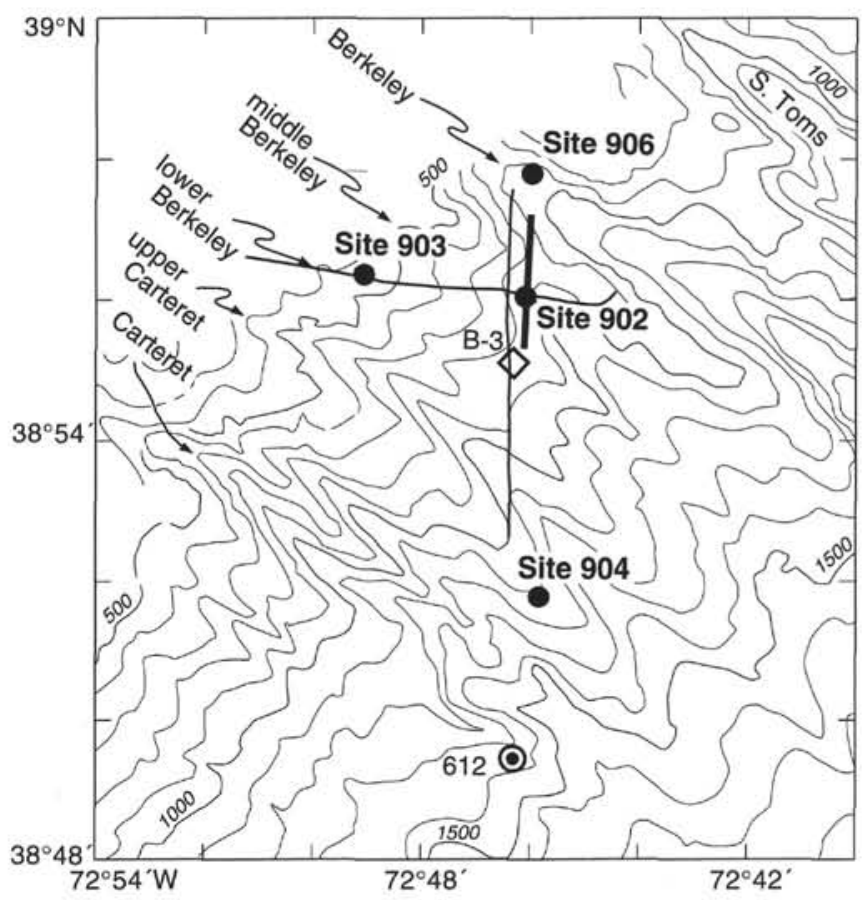

Figure 1. SeaBeam bathymetry and continental slope sites drilled during Leg 150 (Sites 902, 903, 904, and 906). Also shown are DSDP Site 612 (Leg 95) and the COST-B3 well. Thin lines represent parts of Leg 150 seismic sections shown in Figures 2A and 2B, and heavy line indicates part of Maurice Ewing Cruise 9009 MCS Line 1027 shown in Figure 2C. Modified from Mountain, Miller, Blum, et al. (1994).

contact with Miocene strata, whereas at the upslope Site 903 it is located approximately in the middle of the 360 -m-thick Pleistocene sequence (Fig. 2). We identified four Pleistocene reflectors at Site 902, and six at Site 903 (Mountain, Miller, Blum, et al., 1994), informally labeled p1 to p6. Most of the reflectors can be associated with a local seismic unconformity, slump structures in cores, strong bulk density contrast, or several of these characteristics (Fig. 2). 

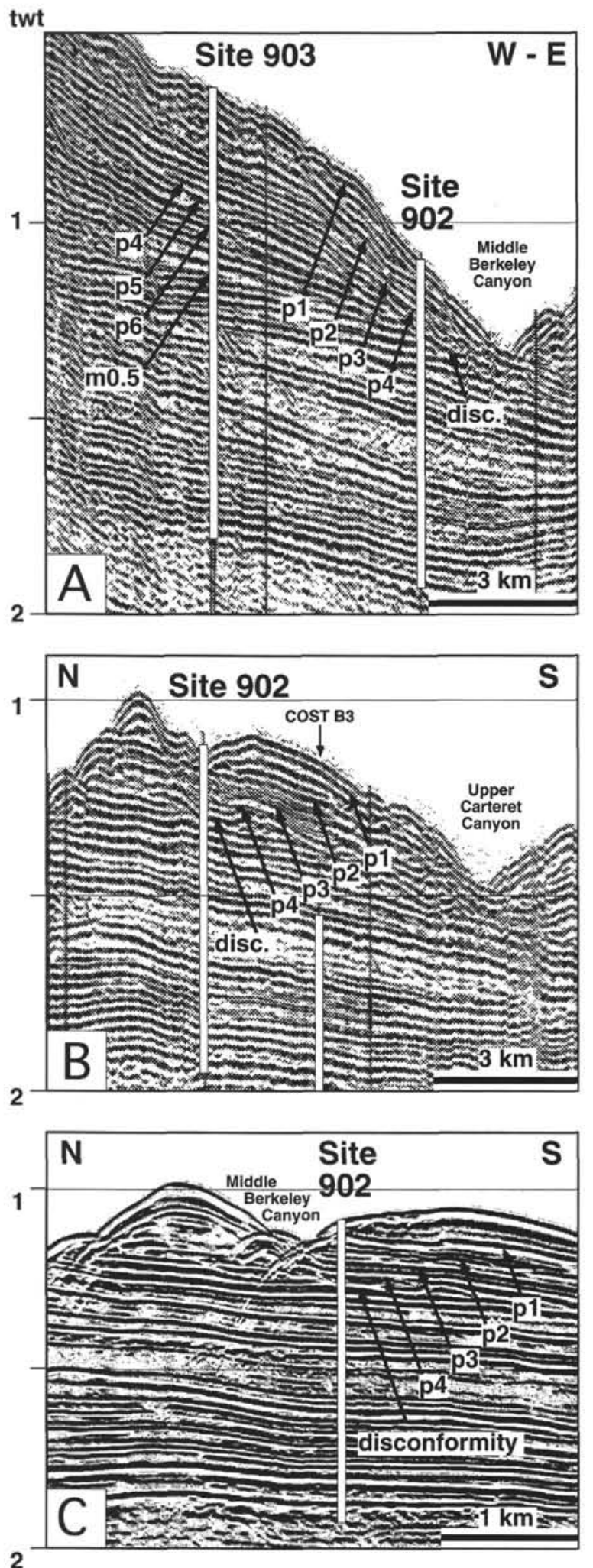

Figure 2. Seismic sections across Sites 902 and 903, acquired during Leg 150 (A, B) and on Maurice Ewing Cruise 9009 (C). Arrows point to reflectors labeled according to Leg 150 informal naming scheme ( $\mathrm{p}=$ Pleistocene, $\mathrm{m}=$ Miocene). Modified from Mountain, Miller, Blum, et al. (1994).
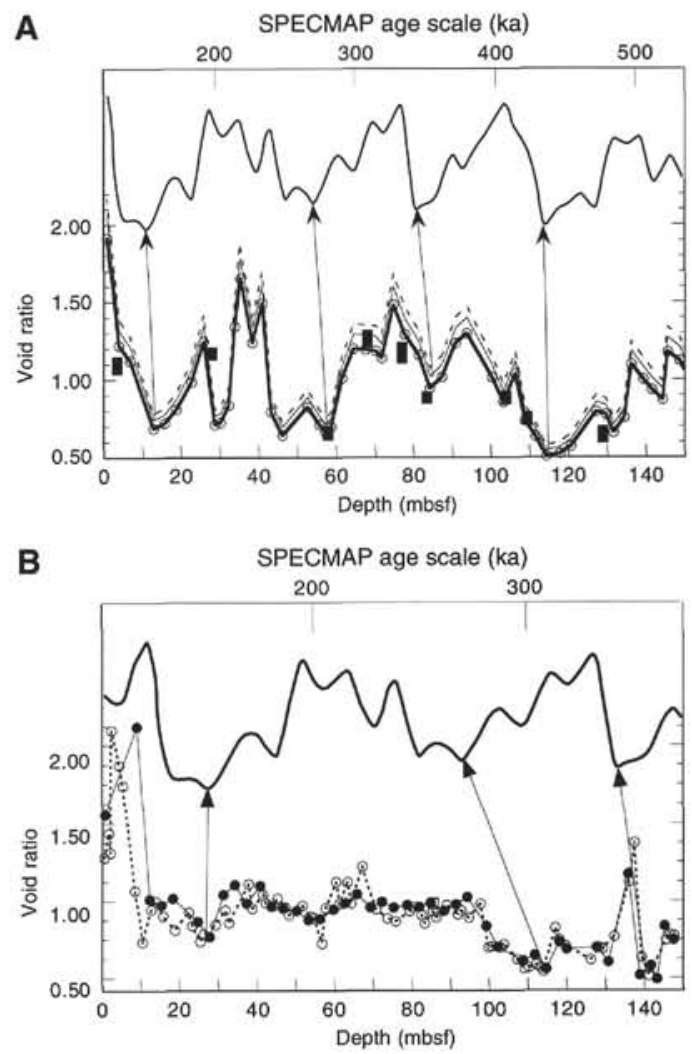

Figure 3. Results of shipboard and shore-based moisture and density measurements (expressed as void ratio) and comparison with SPECMAP composite $\delta^{18} \mathrm{O}$ age model (smooth curves above the void ratio curves). A. Hole 902D. Thin dashed line is uncorrected void ratio. Thin continuous line is void ratio corrected for effects of wet volume measurements in pycnometer. Thick solid line with circles is void ratio corrected additionally for rebound. Solid squares are two or three shore-based measurements from cuttings of consolidation sample. B. Hole 903B. Solid circles are shipboard measurements. Open circles are shore-based measurements. Only one sample has been successfully tested for consolidation so far (open square at $83 \mathrm{mbsf}$ ).

Shipboard physical properties measurements (density, porosity, magnetic susceptibility) produced Pleistocene records correlative with the SPECMAP age scale, which is based on an oxygen isotope composite curve (Imbrie et al., 1984; Mountain, Miller, Blum, et al., 1994). This not only provides the time frame for the Pleistocene stratigraphy, but also demonstrates that the observed cyclic variations in these properties are indeed a proxy for climatic changes. The uppermost $150 \mathrm{~m}$ examined was deposited in approximately $500 \mathrm{ka}$ in Hole $902 \mathrm{D}$ and in approximately $275 \mathrm{ka}$ in Hole 903B, yielding average sedimentation rates of about 0.30 and $0.55 \mathrm{~m} / \mathrm{k} . \mathrm{y}$., respectively (Fig. 3). It can easily be observed from the shipboard physical properties data that the average bulk density, porosity, and void ratio are constant over the Pleistocene interval. Assuming that there are no major changes in lithology and no significant cementation over this interval, the lack of downhole increase in bulk density must be explained at least in part by increasing excess pore pressures arresting compaction. We present here the preliminary results of maximum past stress analysis which allows estimation of excess pore pressures and then compare these with void ratio variations, the proxy for sealevel changes.

A total of 34 whole-round samples were taken aboard ship for shore-based consolidation and permeability testing. Most of these samples (30) were from cores retrieved with the advanced hydraulic piston corer and depths of less than $150 \mathrm{mbsf}$; four samples were 
Table 1. Samples tested for this study.

\begin{tabular}{|c|c|c|}
\hline $\begin{array}{l}\text { Core, section, } \\
\text { interval }(\mathrm{cm})\end{array}$ & $\begin{array}{l}\text { Depth } \\
\text { (mbsf) }\end{array}$ & Visual sediment description (shipboard) \\
\hline \multicolumn{3}{|l|}{ 150-902D- } \\
\hline $1 \mathrm{H}-3,140-143$ & 3.45 & Light gray silty clay, thinly color-banded \\
\hline $3 \mathrm{H}-3,140-143$ & 26.40 & Silty clay with very fine sand \\
\hline $6 \mathrm{H}-5,140-143$ & 57.90 & Dark gray clayey silt \\
\hline $7 \mathrm{H}-6,140-143$ & 68.13 & Color-mottled clay \\
\hline $8 \mathrm{H}-5,142-145$ & 76.92 & Gray, homogenous clay to silty clay \\
\hline $9 \mathrm{H}-3,140-143$ & 83.40 & Olive gray, homogenous silty clay \\
\hline $11 \mathrm{H}-4,140-143$ & 103.90 & Mottled clay \\
\hline $12 \mathrm{H}-2,120-123$ & 109.27 & Sandy clayey silt \\
\hline $14 \mathrm{H}-2,90-93$ & 128.90 & Dark gray silty clay \\
\hline \multicolumn{3}{|l|}{ 150-903B- } \\
\hline $10 \mathrm{H}-5,140-143$ & 85.47 & Homogenous, pinkish-gray silty clay \\
\hline
\end{tabular}

from cores taken with the extended core barrel between 150 and 466 mbsf. Logistical delays, personnel changes, and equipment failure allowed only 14 samples to be processed to this date. Of these, 10 samples of undisturbed core material were tested successfully for geotechnical properties. All tested samples consist of silty mud, with some dispersed fine sand (Table 1).

\section{METHODS}

\section{Moisture Content, Density, and Related Properties}

Moisture content was determined using saturated, wet mass and dry mass after $24 \mathrm{hr}$ oven drying at $105^{\circ} \mathrm{C}$. A helium gas pycnometer was used to determine volumes of saturated, wet and subsequently oven-dried samples. From these measurements, wet-bulk density, grain density, porosity, and void ratio were calculated. Variations in these properties are used to interpret relative eustatic sea-level changes, to integrate laboratory results with shipboard measurements, to relate consolidation state of laboratory samples to basic physical properties, and to calculate the effective stress profile under assumption of hydrostatic equilibrium.

The shipboard procedures included measurement of wet-bulk volume on all samples and measurement of dry volume on approximately one-half the samples. Bulk density and grain density can be calculated directly using wet volume and mass, and dry volume and mass, respectively. In addition, using the water contents derived from oven drying, wet-bulk density can be calculated from the dry-volume measurement and grain density can be calculated from wet-volume measurements. This provides a control in regard to possible errors introduced by one or the other method of volume measurement, oven drying, etc.

Sampling density was approximately one every $3 \mathrm{~m}$ over the uppermost $150 \mathrm{~m}$ in Holes 902D and 903B. Based on the importance of these measurements as recognized at Site 902, an additional 82 samples were taken on the ship from Hole 903B for shore-based measurements using the same methods that were used on the ship. Moisturedensity measurements were also performed on cuttings from the whole-round samples used for consolidation and permeability measurements (see below). This allowed integration of shore-based results with shipboard measurements.

\section{Consolidation Tests}

Consolidation tests are used to estimate the maximum degree of consolidation the sediment has experienced in the past. The maximum past effective stress $\sigma^{\prime}{ }_{v p}$, derived from a sample's response to a series of applied loads, is compared to the effective stress at hydrostatic equilibrium $\sigma_{10}^{\prime}$, calculated from bulk-density measurements. Ten-centimeter-long whole-round samples were cut from the cores immediately after they arrived on the catwalk. They were capped and sealed in wax to prevent loss of moisture.
Samples of about 16-mm thickness and 50-mm diameter were prepared from the whole-round samples for uniaxial consolidation testing. Residues from sample preparation were immediately filled in $10-\mathrm{cm}^{3}$ vials and measured for mass and volume. After the samples were mounted in a Rowe-type pressure cell, they were back-pressured to $500 \mathrm{kPa}$ to dissolve all remaining air in the pore water. Three hydraulic actuators with precision of $\pm 1 \mathrm{kPa}$ were used to control axial, pore, and back pressures independently.

Incremental loading steps used were usually $20,40,75,150,300$, 600,1200 , and $2400 \mathrm{kPa}$, with an unloading and reloading cycle from 1200 to 75 and back to $1200 \mathrm{kPa}$. Approximately one day was allowed for each consolidation step. The associated change in height was measured with a linear variable differential transformer (LVDT), and millimeters were calculated using the calibration slope from multiple standard measurements and the intercept determined from the initial reading for each sample. Measurements are accurate to at least $0.001 \mathrm{~mm}$, which translates into void ratio changes of about 0.001 or a precision of $0.1 \%$.

The apparent maximum stress the sediment experienced, $\sigma_{v p}^{\prime}$, was determined by two methods. First, the graphical method of Casagrande (1936) was used to derive $\sigma_{v p(g r a p h)}^{\prime}$. This method requires that the transition from the reloading curve to the virgin compression curve be well defined on the semilogarithmic plot of void ratio vs. effective stress. The second method uses the recompression slope, $\mathrm{C}_{r}$, to estimate the in situ void ratio. $\mathrm{C}_{r}$ is usually smaller and more representative of the recompression index than the slope of the initial recompression owing to various factors related to sampling. The horizontal through the corrected void ratio was then "intersected" with the virgin compression curve to derive the effective stress $\sigma^{\prime}{ }_{\text {vp }(\text { calc }}$ (Bryant et al., 1986; Fisher et al., 1994). Both methods used potentially underestimate $\sigma_{v p}^{\prime}$ because the in situ virgin curve is thought to be somewhat steeper than the one determined in the laboratory.

The two estimates of preconsolidation stress, $\sigma_{v p}^{\prime}$, were then compared with the calculated effective stress at hydrostatic equilibrium, $\sigma_{v 0}^{\prime}$, to determine the overconsolidation ratio $\left(\mathrm{OCR}=\sigma_{v p}^{\prime} / \sigma_{v 0}^{\prime}\right)$ and the overconsolidation difference $\left(\mathrm{OCD}=\sigma_{v p}^{\prime}-\sigma_{v 0}^{\prime}\right.$; Bryant and Bennett, 1988).

\section{Permeability Tests}

On each consolidation sample, four to seven permeability tests at different loading steps were performed. At each step, three different flow rates were applied in two directions (six measurements) with a medical constant-flow pump as described by Olsen et al. (1985). Water flux through the sample was measured with a differential pressure transducer (DPD) connected to the top and the bottom of the sample. The voltage readings from the DPD were calibrated with the digital pressure controllers over the $\pm 35-\mathrm{kPa}$ range, and resolution within this range was at least $0.1 \mathrm{kPa}$. This method allows application of reasonably low heads for reasonably short periods of time $(<1 \mathrm{hr})$, keeping the risk of seepage consolidation at a minimum.

For each measurement, hydraulic conductivity $K$ was calculated using Darcy's law relating the flow rate $Q$ to the hydraulic gradient $\Delta \mathrm{H} / \Delta \mathrm{h}$, or

$$
Q=-K \times A \times \Delta \mathrm{H} / \Delta \mathrm{h},
$$

where $A=$ the sample cross-sectional area, $\Delta \mathrm{H}=$ the hydraulic head, and $\Delta \mathrm{h}=$ the sample thickness. The hydraulic head, $\Delta \mathrm{H}$, was calculated from the measured differential pressure, $\Delta \mathrm{p}$, by

$$
\Delta \mathrm{H}=\Delta \mathrm{p} /(\rho \times g),
$$

where $\rho=$ the density of water and $g=$ the acceleration caused by gravity. Intrinsic permeability, $k$, is derived from 
Table 2. Consolidation test results.

\begin{tabular}{|c|c|c|c|c|c|c|c|c|c|c|c|c|}
\hline \multirow{2}{*}{$\begin{array}{l}\text { Core, section, } \\
\text { interval }(\mathrm{cm})\end{array}$} & \multirow{2}{*}{$\begin{array}{l}\text { Depth } \\
\text { (mbsf) }\end{array}$} & \multirow{2}{*}{$\begin{array}{l}\sigma_{v 0^{\prime}}^{\prime} \\
(\mathrm{kPa})\end{array}$} & \multirow[b]{2}{*}{$\mathrm{C}_{c}^{\mathrm{b}}$} & \multirow[b]{2}{*}{$\mathrm{C}_{r}^{\mathrm{c}}$} & \multicolumn{2}{|c|}{ Void ratio $e_{0}$} & \multicolumn{2}{|c|}{ Precons. stress $\sigma_{p}^{\prime}$} & \multicolumn{2}{|c|}{$\mathrm{OCR}^{\mathrm{g}}$} & \multicolumn{2}{|c|}{$\mathrm{OCD}^{\mathrm{g}}$} \\
\hline & & & & & Lab. & Calc. $^{d}$ & Graph. ${ }^{e}$ & Calc. ${ }^{f}$ & Graph. & Calc. & Graph. & Calc. \\
\hline \multicolumn{13}{|l|}{$150-902 \mathrm{D}$} \\
\hline $1 \mathrm{H}-3,140-143$ & 3.45 & 25 & 0.232 & 0.050 & 1.190 & 1.120 & 116 & 117 & 4.7 & 4.7 & 91 & 92 \\
\hline $3 \mathrm{H}-3,140-143$ & 26.40 & 247 & 0.259 & 0.034 & 1.260 & 1.179 & 346 & 250 & 1.4 & 1.0 & 99 & 3 \\
\hline $6 \mathrm{H}-5,140-143$ & 57.90 & 510 & 0.095 & 0.011 & 0.711 & 0.682 & 403 & 239 & 0.8 & 0.5 & -107 & -271 \\
\hline $7 \mathrm{H}-6,140-143$ & 68.13 & 600 & 0.372 & 0.037 & 1.365 & 1.263 & 598 & 566 & 1.0 & 0.9 & -3 & -34 \\
\hline $8 \mathrm{H}-5,142-145$ & 76.92 & 666 & 0.371 & 0.042 & 1.260 & 1.141 & 695 & 725 & 1.0 & 1.1 & 29 & 59 \\
\hline $9 \mathrm{H}-3,140-143$ & 83.40 & 721 & 0.212 & 0.024 & 0.955 & 0.886 & 761 & 644 & 1.1 & 0.9 & 40 & -77 \\
\hline $11 \mathrm{H}-4,140-143$ & 103.90 & 890 & 0.183 & 0.032 & 0.953 & 0.860 & 616 & 693 & 0.7 & 0.8 & -274 & -197 \\
\hline $12 \mathrm{H}-2,120-123$ & 109.27 & 938 & 0.109 & 0.018 & 0.810 & 0.756 & 403 & 330 & 0.4 & 0.4 & -535 & -608 \\
\hline $14 \mathrm{H}-2,90-93$ & 128.90 & 1144 & 0.065 & 0.017 & 0.696 & 0.642 & 739 & 422 & 0.6 & 0.4 & -405 & -722 \\
\hline \multirow{2}{*}{$\begin{array}{l}150-903 \mathrm{~B}- \\
10 \mathrm{H}-5,140-143\end{array}$} & & & & & & & & & & & & \\
\hline & 85.47 & 728 & 0.137 & 0.024 & 1.018 & 0.948 & 256 & 141 & 0,4 & 0.2 & -472 & -587 \\
\hline
\end{tabular}

${ }^{\mathrm{a}}$ Effective stress calculated from bulk density, assuming hydrostatic equilibrium.

${ }^{\mathrm{b}}$ Compression index (slope of virgin curve).

${ }^{\mathrm{c}} \mathrm{Recompression}$ index (slope of recompression curve).

${ }^{\mathrm{d}}$ Corrected initial void ratio using recompression index.

${ }^{\circ}$ Maximum past effective stress from Casagrande (1936) method.

${ }^{f}$ Maximum past effective stress from alternate method using intersection of horizontal thorough calculated void ratio with virgin curve.

${ }^{\mathrm{g}} \mathrm{OCR}=$ overconsolidation rate, and $\mathrm{OCD}=$ overconsolidation difference.

$$
K=k \times(\rho \times g / \mu),
$$

where $\rho$ and $\mu=$ the density and viscosity of water at laboratory conditions, respectively.

Permeability could also be calculated using the Terzaghi theory of consolidation and "curve fitting" methods after Casagrande and Taylor (Holtz and Kovacs, 1981). Judging from the graphical procedures involved and the frequent citation of low permeability estimates by this method, it appears to be inferior to the direct measurement by the flow pump method.

\section{RESULTS}

\section{Densities, Porosities, and Void Ratios}

Densities calculated from wet-volume measurements (referred to as B-type) are consistently higher than those calculated from dry-volume measurements (referred to as C-type). Although B-type bulk densities match downhole bulk density measurements better than the lower C-type measurements, the B-type grain densities are clearly unrealistic. An analysis of these phenomena related to the use of a gas pycnometer is beyond the scope of this study and will be presented and discussed in a separate paper. As for the data used here, we decided to use C-type densities based on evidence that the wet-volume measurements are associated with a larger error.

For Hole 902D samples, only B-type densities were available. These needed to be corrected in order to be compatible with the more accurate $\mathrm{C}$-type densities. We used the average of all ratios of C-type to B-type densities from all records of all Leg 150 holes where C-type measurements were available. The deviation from the average ratio could be used as an indicator of measurement quality. Some records with large deviations were actually annotated by shipboard scientists as having experienced more air-drying than usual before measurement, etc. We eliminated all records in which the ratio deviated more than $20 \%$ from the ratio mean, or about $5 \%$ of all records. The corrections based on the good records and applied to B-type density values are $\rho_{b(c o r r)}=0.976 \rho_{b(B)}$ and $\rho_{s(c o r r)}=0.951 \rho_{s(B)}$, where $\rho_{b}$ is the bulk density and $\rho_{s}$ is the grain density.

Results of the 82 samples measured on shore more than $1 \mathrm{yr}$ after the cruise were compatible with the shipboard results (Fig. 3B). Unfortunately, the climatic signal is much more subdued at Site 903 than at Site 902 for yet unresolved reasons (Fig. 3), but most likely related to the depositional environment.

We will use the void ratio rather then bulk density or porosity from here on. Void ratio was calculated as

$$
e=\mathrm{W}_{s} \rho_{s} / \rho_{p w},
$$

where $\mathrm{W}_{s}=$ the water content relative to the dry mass, and $\rho_{p w}=$ the pore-water density (assumed to be $1.024 \mathrm{~g} / \mathrm{cm}^{3}$ throughout). The relationship between void ratio and bulk density is

$$
\rho_{b}=\left(\rho_{s}+e \rho_{p w}\right) /(e+1) \text {. }
$$

Void ratio is used to present stress-strain relations later, and it also conveniently matches the SPECMAP curve (Fig. 3). Void ratio was also determined from the residues of sample trimming for the consolidation samples. Two or three subsamples were measured in each case.

An additional correction for rebound was applied to the void ratio values using the consolidation test data presented in the next section. For each consolidation sample, the rebound-corrected void ratio was calculated using the laboratory void ratio and the recompression slope determined in the consolidation test. The average rebound factor from these samples, 0.93 , was then applied to all void ratios measured and corrected for wet volume pycnometry. Original and corrected values are illustrated for Hole 902D (Fig. 3A).

\section{Consolidation Results}

Nine consolidation tests were successfully completed on samples from Hole 902D, and one test was completed on a sample from Hole 903B. The results are summarized in Table 2 and illustrated in Figure 4. Values for the compression index, $\mathrm{C}_{c}$, and recompression index, $C_{r}$, range from 0.065 to 0.372 and 0.011 to 0.037 , respectively. This range as well as the general difference of an order of magnitude between the two indices represent realistic values (Holtz and Kovacs, 1981). Both $C_{c}$ and $C_{r}$ vary significantly with the initial void ratio of the sample: the higher the void ratios, the steeper the consolidation slopes (Fig. 5). This means that sediment from interglacial periods containing more initial porosity is more compressible than sediment from glacial periods with higher initial bulk density. $\mathrm{C}_{c}$ and $\mathrm{C}_{r}$ do not vary systematically with depth.

The two estimates of preconsolidation stress obtained by the two methods are reasonably close. There is no systematic difference between the two methods: the Casagrande (1936) method yields higher values than the alternate method for some samples whereas the opposite is true for other samples. Both OCR and OCD have been calculated for both methods and the results are consistent in terms of consolidation state (Table 2; Figs. 4, 6). 

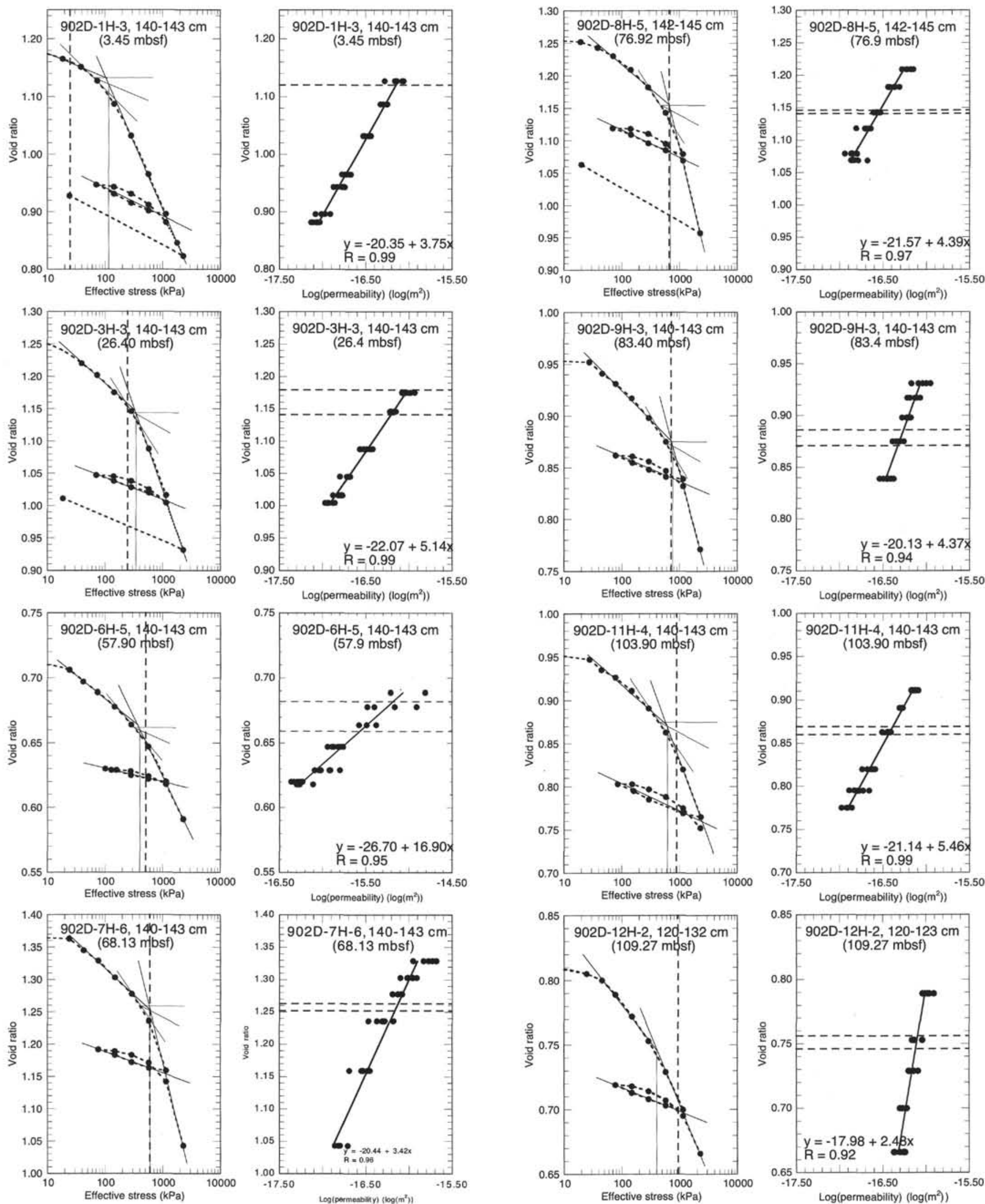

Figure 4. Results of consolidation and permeability tests on nine samples from Hole 902D and one sample from Hole 903B. Each sample is represented by a pair of consolidation (left) and permeability (right) plots at the same void ratio scale. Dashed vertical lines on consolidation plots are effective stresses calculated from bulk density measurements assuming hydrostatic equilibrium. Thin vertical lines are maximum past effective stresses derived by the graphical method of Casagrande (1936). Dashed horizontal lines on permeability plots represent void ratios at maximum past effective stresses derived by the Casagrande (1936) method and by the alternate method, respectively (see text). 

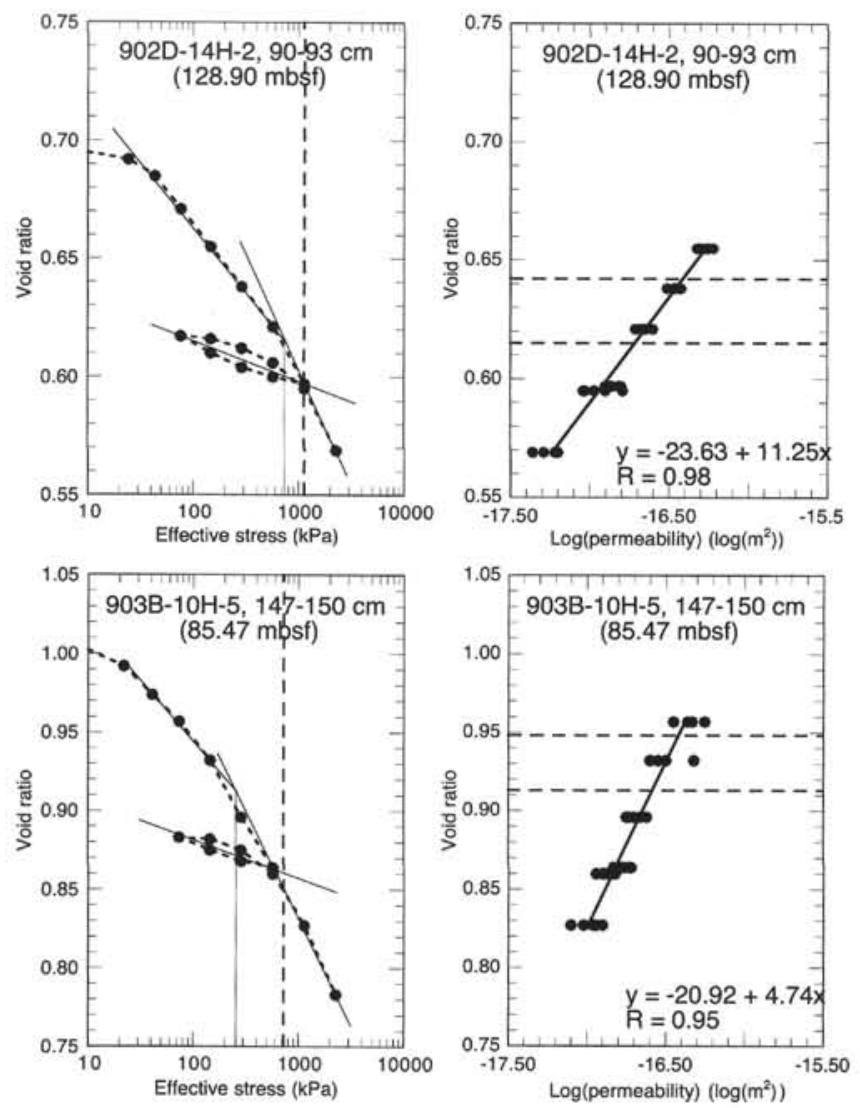

Figure 4 (continued).

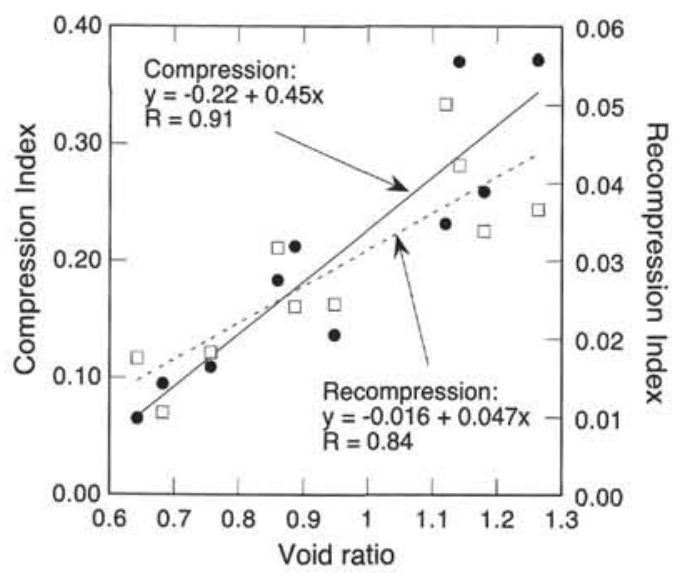

Figure 5. Relationship between void ratio and compression index $\mathrm{C}_{c}$ (circles), and between void ratio and recompression index $\mathrm{C}_{r}$ (squares). Both indices vary with void ratio; they do not correlate with depth.

Only Sample 150-902D-1H-3, 140-143 cm, at 3.5 mbsf is clearly overconsolidated. Due to the shallow depth, an OCD of only $90 \mathrm{kPa}$ translates into a seemingly high OCR of more than 4 . Subsequent samples in Hole 902D at 26.4, 68.1,76.9, and 83.5 mbsf are normally consolidated, with an underconsolidated sample at $57.9 \mathrm{mbsf}$ (OCR $0.5 \sim 0.8$ ). Below $83.5 \mathrm{mbsf}$, the sediment becomes dramatically underconsolidated. The steep trend between about 80 and $110 \mathrm{mbsf}$ is apparently slowed or even reversed with the deepest sample available at $128 \mathrm{mbsf}$.

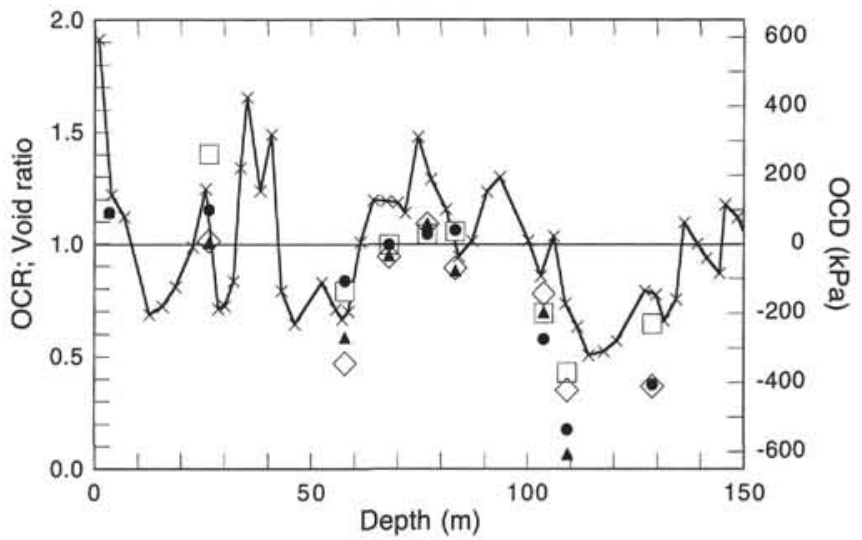

Figure 6. Relationships between void ratio, overconsolidation rate (OCR), and overconsolidation difference (OCD). Squares and circles represent OCR and OCD derived by the Casagrande (1936) method, respectively. Diamonds and triangles represent $\mathrm{OCR}$ and $\mathrm{OCD}$ derived by the alternate method, respectively. Crosses connected by solid line are void ratios. Note that normal consolidation $(\mathrm{OCR}=1)$ coincides with void ratio $e=1$, which is approximately the average void ratio of the section examined. The OCD is scaled to fit, and it is apparent that variations in OCR and OCD correlate well.

\section{Permeability Results}

Good to excellent correlation exists between the log of measured permeabilities and void ratio changes as a result of incremental loading of the sample (Fig. 4). The $\Delta \log k / \Delta e$ slopes are between 2 and 6 , except for Sample 150-902D-6H-5, 140-143 cm, which has a slope of 17 (Table 3, Fig. 4; note that the $x$ and $y$ axes are reversed for convenience in Fig. 4). This sample was observed to be rich in silt and very fine sand, cracked intensely by escaping gas, and has extremely low compression and recompression indices (Table 2). It appears that the initially higher permeability is more severely reduced with decreasing void ratio than for the other samples with lower initial permeability. Although the higher silt and sand content reduces compressibility, it is not high enough to maintain porosity and allows the packing of clay and rapid reduction of permeability under confining stress.

In situ permeability was calculated by "intersecting" the void ratios at the maximum past effective stresses (derived by both methods explained above) with the permeability regression curve. All samples examined showed in situ permeabilities over a narrow range of $4.3 \times$ $10^{-16}$ to $7.810^{-17} \mathrm{~m}^{2}$ (Table 3; Fig. 4). Although the values appear to be typical for silty clays, their spread over little more than one order of magnitude, and only one-half an order of magnitude if the sample at $58 \mathrm{mbsf}$ is excluded, is rather remarkable. Sample $150-902 \mathrm{D}-6 \mathrm{H}-$ $5,140-143 \mathrm{~cm}$, has a higher in situ permeability of $4.28 \times 10^{-16} \mathrm{~m}^{2}$ owing to its relatively higher silt and fine sand content.

The modest variations in permeability do not correlate with depth or with void ratio in cross-plots. A poor correlation exists with the maximum past effective stress derived from the consolidation tests (Fig. 7). Plotting the in situ permeabilities over the void ratio curve gives the impression of a rough inverse correlation (Fig. 8); however, removing only the extreme permeability value for Sample 150-902D$6 \mathrm{H}-5,140-143 \mathrm{~cm}$, makes such a correlation questionable.

\section{DISCUSSION}

Consolidation of marine, clay-rich sediment is the result of interparticle bonding, loss of interstitial water, and cementation, controlled mainly by clay mineralogy, permeability, and diagenetic pa- 
Table 3. Permeability test results.

\begin{tabular}{|c|c|c|c|c|c|c|c|c|c|c|c|}
\hline \multirow{2}{*}{$\begin{array}{l}\text { Core, section, } \\
\text { interval }(\mathrm{cm})\end{array}$} & \multirow{2}{*}{$\begin{array}{l}\text { Depth } \\
\text { (mbsf) }\end{array}$} & \multicolumn{3}{|c|}{ Permeability $\left(\log \left[\mathrm{m}^{2}\right]\right)^{a}$} & \multicolumn{2}{|c|}{ Void ratio at $\sigma_{v p}^{\prime}{ }^{b}$} & \multicolumn{4}{|c|}{ Permeability at $\sigma_{v p}^{\prime}\left(\log \left[\mathrm{m}^{2}\right]\right)$} & \multirow{2}{*}{$\frac{\text { Permeability at } \sigma_{v p}}{\text { Average }\left(\mathrm{m}^{2}\right)}$} \\
\hline & & Slope & Intercept & $R$ & Graph. & Calc. & Graph. & Calc. & Ave. ${ }^{c}$ & $\Delta \log k^{d}$ & \\
\hline \multicolumn{12}{|l|}{$150-902 \mathrm{D}$} \\
\hline $1 \mathrm{H}-3,140-143$ & 3.45 & 3.76 & -15.33 & 0.99 & 1.120 & 1.120 & -16.15 & -16.15 & -16.15 & 0.00 & $7.08 \times 10^{-17}$ \\
\hline $3 \mathrm{H}-3,140-143$ & 26.40 & 5.14 & -17.05 & 0.99 & 1.141 & 1.179 & -16.21 & -16.01 & -16.11 & 0.20 & $7.81 \times 10^{-17}$ \\
\hline $6 \mathrm{H}-5,140-143$ & 57.90 & 16.93 & -21.71 & 0.95 & 0.659 & 0.682 & -15.56 & -15.17 & -15.37 & 0.39 & $4.28 \times 10^{-16}$ \\
\hline $7 \mathrm{H}-6,140-143$ & 68.13 & 3.42 & -15.43 & 0.95 & 1.252 & 1.263 & -16.16 & -16.12 & -16.14 & 0.04 & $7.26 \times 10^{-17}$ \\
\hline $8 \mathrm{H}-5,142-145$ & 76.92 & 4.38 & -16.54 & 0.96 & 1.146 & 1.141 & -16.54 & -16.56 & -16.55 & 0.02 & $2.82 \times 10^{-17}$ \\
\hline $9 \mathrm{H}-3,140-143$ & 83.40 & 4.35 & -15.10 & 0.94 & 0.871 & 0.886 & -16.32 & -16.26 & -16.29 & 0.07 & $5.12 \times 10^{-17}$ \\
\hline $11 \mathrm{H}-4,140-143$ & 103.90 & 5.46 & -16.12 & 0.99 & 0.869 & 0.860 & -16.40 & -16.44 & -16.42 & 0.05 & $3.80 \times 10^{-17}$ \\
\hline $12 \mathrm{H}-2,120-123$ & 109.27 & 2.48 & -12.95 & 0.92 & 0.746 & 0.756 & -16.13 & -16.11 & -16.12 & 0.02 & $7.63 \times 10^{-17}$ \\
\hline $14 \mathrm{H}-2,90-93$ & 128.90 & 11.21 & -18.59 & 0.98 & 0.615 & 0.642 & -16.71 & -16.41 & -16.56 & 0.30 & $2.76 \times 10^{-17}$ \\
\hline \multicolumn{12}{|l|}{$150-903 \mathrm{~B}-$} \\
\hline $10 \mathrm{H}-5,140-143$ & 85.47 & 4.70 & -15.86 & 0.95 & 0.913 & 0.948 & -16.59 & -16.43 & -16.51 & 0.17 & $3.09 \times 10^{-18}$ \\
\hline
\end{tabular}

${ }^{a}$ From regression of test results (see Fig. 2)

${ }^{\mathrm{b}}$ From maximum past effective stress solutions by the Cassagrande (1936) method (Graph.) and an alternate method (Calc.; see text), respectively.

${ }^{c}$ Average of solutions from two methods (Graph. and Calc.).

${ }^{\mathrm{d}}$ Difference between two solutions (Graph. and Calc.) as an error estimate.

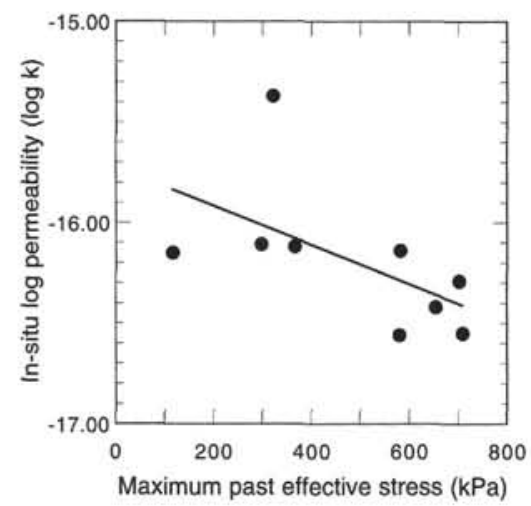

Figure 7. Relationship between maximum past effective stress (in situ stress) and the logarithm of in situ permeability.

rameters, respectively. The relative significance of each process varies with time and burial depth. In the young (Pleistocene) sediments of limited burial depth ( $150 \mathrm{mbsf})$ and relatively uniform composition (terrigenous silty clays) cementation can be excluded as a major control of consolidation, leaving loss of interstitial water as the prime control.

Consolidation of clay near the seafloor, to a depth of a few meters, is controlled mainly by interparticle bonding. Overconsolidation is commonly observed at shallow depth in marine sediments (and even more so in terrestrial sediments where desiccation is another important factor). For Sample 150-902D-1H-3, 140-143 cm, at $3.5 \mathrm{mbsf}$, the OCR of 4.7 merely represents an OCD of about $90 \mathrm{kPa}$. This corresponds to a burial thickness of about $10 \mathrm{~m}$ assuming sediment bulk densities observed at such depths. Another process responsible for overconsolidation near the surface is the removal of a sediment section. The uppermost Pleistocene section is missing at this site (Mountain, Miller, Blum, et al., 1994), a potential layer of about $120 \mathrm{~m}$ thickness assuming a similar sedimentation rate as for the middle Pleistocene section. If such a layer had existed and later been eroded, the sample at 3.5 mbsf should be overconsolidated to about $1 \mathrm{MPa}$. This is clearly not the case and we speculate that the lack of an upper Pleistocene section is the result of proximity to the Middle Berkeley Canyon thalweg where sediments were flushed down the canyon continuously since Stage 5.4 (about since the last interglacial at 120 ka; Mountain, Miller, Blum, et al., 1994) during that period without ever accumulating. Slump structures observed in the uppermost $20 \mathrm{~m}$ of sediment may indicate the transition from a depositional to an erosional state. Canyon shifting, such as described by Pratson et al.

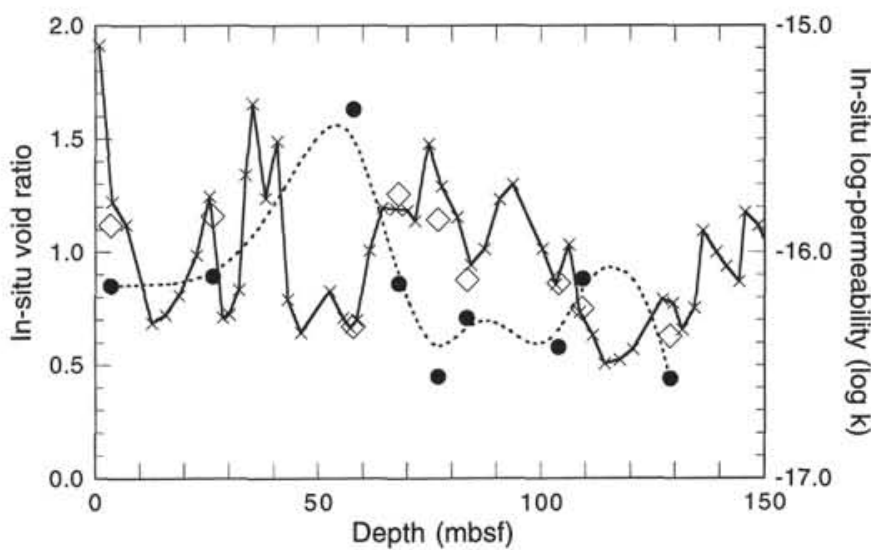

Figure 8. Relationship between void ratio (crosses for Leg 150 shipboard samples and diamonds for consolidation samples) and the logarithm of in situ permeability (circles) as functions of depth.

(1994), is probably responsible for the lack of uppermost Pleistocene sediment deposition at this site.

The mostly normal consolidation rates observed in samples from about 25 to about $85 \mathrm{mbsf}$ depth indicate that the pore pressures are generally in equilibrium with the hydrostatic pressure. This means that permeabilities of these sediments allow dewatering at a rate sufficient to maintain equilibrium with hydrostatic pressure. Underconsolidation of Sample 150-902D-6H-5, 140-143 cm, at $58 \mathrm{mbsf}$, coincides with a low initial void ratio and relatively high permeability (Table 3; Figs. 4, 6, 8). Underconsolidation at $58 \mathrm{mbsf}$ as well as for all samples deeper than 80 mbsf is associated with excess pore-water pressures resulting in effective stresses lower than those expected for hydrostatic equilibrium. The excess pore pressure is approximately the difference between $\sigma_{v 0}^{\prime}$ and $\sigma_{v p}^{\prime}$, or about 500 to $700 \mathrm{kPa}$ between 110 and 130 mbsf (Fig. 9).

Underconsolidation essentially is a state of disequilibrium in which the sediment has not fully consolidated under the existing overburden total stress. It is associated either with rapid sedimentation and a delay in pore-pressure dissipation or by in situ production of gas rising to a level where it exists in its free phase. Gas in solution will not change the pore-water pressure in the soil as long as there is no free gas associated with it (e.g., Sangrey, 1977; Esrig and Kirby, 1977; Whelan et al., 1976). Evidence of free gas bubbles has been reported from offshore samples, and reconstituted samples containing uniformly distributed, undissolved gas bubbles have been prepared and analyzed in the laboratory (Sills et al., 1991). Observed gas bub- 


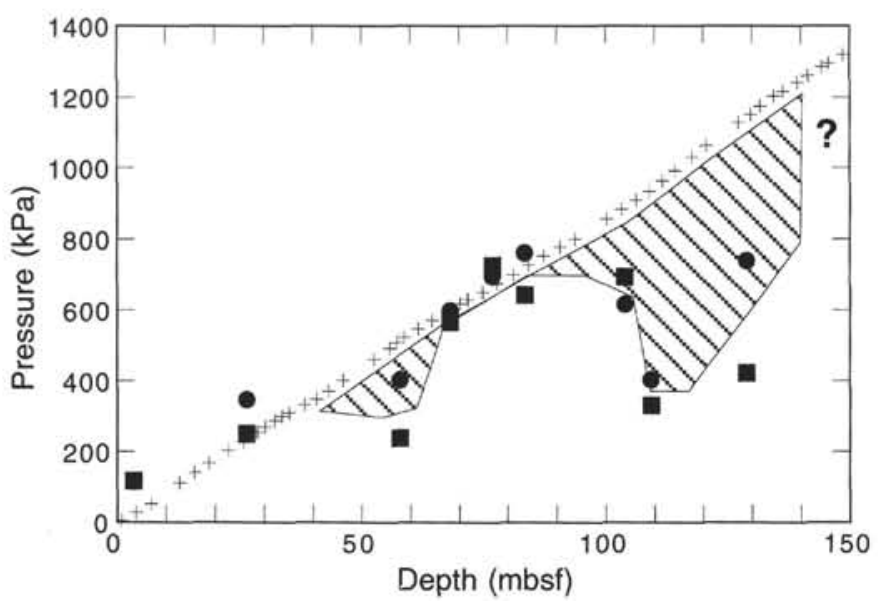

Figure 9. State of consolidation from Hole 902D samples. Circles and squares represent maximum past effective stresses derived by the Casagrande (1936) and the alternate method, respectively. Crosses are effective stresses calculated for hydrostatic equilibrium. Hatched area represents underconsolidation and excess pore pressure up to $600 \mathrm{kPa}$.

ble size distribution show a significant proportion of bubbles one to two orders of magnitude larger than interparticle voids. Surface tension constraints require that gas pressure must always be greater than the pore water pressure, and at the same time sets limits to the maximum possible difference between gas and pore water pressure (Wheeler et al., 1989). At the same time, cavity expansion and contraction limits the difference between gas pressure and the mean total stress. Gas pressure should therefore remain almost unaffected by changes to the total stress or pore water pressure (Wheeler et al., 1989). However, as more free gas is generated, the total pore pressure will continue to increase.

On Leg 150, we observed significant gas escape from recovered cores starting with Core $150-902 \mathrm{D}-6 \mathrm{H}$ and continuing moderately through Cores $150-902 \mathrm{D}-7 \mathrm{H}$ to $9 \mathrm{H}$. Gas escape was most intense in Cores $150-902 \mathrm{D}-9 \mathrm{H}$ through $13 \mathrm{H}$ (about $80-120 \mathrm{mbsf}$ ). The show abruptly decreased with Core 150-902D-14H at about $130 \mathrm{mbsf}$, or at the base of the Pleistocene sequence. These observations of gas escape correlate with our intervals of underconsolidation. Although the gas recovered with vacutainers was determined to be biogenic methane produced in situ, we do not know if and at which levels free gas might have existed in situ. The recovered gas may be the product of exsolution of methane which was dissolved in situ, or the gas may have migrated from greater depth. Wheeler (1990) showed that bubbles of a realistic size should move upward only in extremely weak sediments, and that buoyancy-induced movement of relatively large bubbles in fine-grained sediments is unlikely to occur at depth greater than a few meters below the seafloor. At this time and pending further analysis, we may therefore state that the correlation of underconsolidation with significant gas escape indicates that in situ produced methane may be a major contributor to the fluid overpressure, and that free gas is likely to exist at these levels.

The intervals of underconsolidation also correlate with intervals of relatively low void ratio (Fig. 8). It could be inferred that void ratio, a signal of climate change-related compositional variations, is controlling pore-pressure dissipation. It could be possible then that "glacial," overpressured gas reservoirs alternate with "interglacial" seals. Although the higher void ratio in the "seal" would intuitively imply higher permeability, this is not indicated by our permeability data. Our permeability data were derived from single-phase tests with distilled water, and perhaps effects of two-phase pore fluids need to be examined as well. In any case, grain-size and mineralogical data will greatly enhance the potential to model and interpret this data set, which we plan to supplement with analyses of further samples for better depth resolution and verification of test results.

In conclusion, these preliminary consolidation tests on silty mud samples from the Pleistocene upper continental slope reveal dramatic underconsolidation near $60 \mathrm{mbsf}$ and from about $85 \mathrm{mbsf}$ to the maximum depth of investigation at $130 \mathrm{mbsf}$. Excess pore pressures at these depths are estimated between 100 and $500 \mathrm{kPa}$ and are most likely related to in situ biogenic gas production. The potential correlation of underconsolidation with cyclic intervals of lower void ratio deposited during glacial times is an interesting result that needs further work including better geotechnical depth resolution, grain-size and mineralogical data, and modeling of various relationships.

\section{REFERENCES}

Bryant, W., Wetzel, A., Taylor, E., and Sweet, W., 1986. Consolidation characteristics and permeability of Mississippi fan sediments. In Bouma, A.H., Coleman, J.M., Meyer, A.W., et al., Init. Repts. DSDP, 96: Washington (U.S. Govt. Printing Office), 797-809.

Bryant, W.R., and Bennett, R.H., 1988. Origin, physical and mineralogical nature of red clays: the Pacific ocean as a model. Geo-Mar. Lett., 8:189249.

Casagrande, A., 1936. The determination of preconsolidation load and its practical significance. In Casagrande, A., Rutledge, P.C., and Watson, J.D. (Eds.), Proc. Ist Int. Conf. Soil Mech. Found. Eng., Am. Soc. Civ. Eng., 3:60-64.

Esrig, M.I., and Kirby, R.C., 1977. Implications of gas content for predicting the stability of submarine slopes. Mar. Geotechnol., Spec. Iss., 2:81-100.

Fisher, A.T., Fischer, K., Lavoie, D., Langseth, M., and Xu, J., 1994. Geotechnical and hydrogeological properties of sediments from Middle Valley, northern Juan de Fuca Ridge. In Mottl, M.J., Davis, E.E., Fisher, A.T., and Slack, J.F. (Eds.), Proc. ODP, Sci, Results, 139: College Station, TX (Ocean Drilling Program), 627-647.

Holtz, R.D., and Kovacs, W.D., 1981. An Introduction to Geotechnical Engineering: Englewood Cliffs, NJ (Prentice-Hall).

Imbrie, J., Hays, J.D., Martinson, D.G., McIntyre, A., Mix, A.C., Morley, J.J., Pisias, N.G., Prell, W.L., and Shackleton, N.J., 1984. The orbital theory of Pleistocene climate: support from a revised chronology of the marine $\delta^{18} \mathrm{O}$ record. In Berger, A., Imbrie, J., Hays, J., Kukla, G., and Saltzman, B. (Eds.), Milankovitch and Climate (Pt. 1), NATO ASI Ser. C, Math Phys. Sci., 126: Dordrecht (D. Reidel), 269-305.

Mountain, G.S., Miller, K.G., Blum, P., et al., 1994. Proc. ODP, Init. Repts., 150: College Station, TX (Ocean Drilling Program).

Mountain, G.S., Miller, K.G., and the Leg 150 Scientific Party, 1994. Sealevel and slope processes reflected off New Jersey. Eos, 75:212-214.

Olsen, H.W., Nichols, R.W., and Rice, T.L., 1985. Low gradient permeability measurements in a triaxial system. Geotechnique, 35:145-157.

Pratson, L.F., Ryan, W.B.F., Mountain, G.S., and Twichell, D.C., 1994. Submarine canyon initiation by downslope-eroding sediment flows: evidence in late Cenozoic strata on the New Jersey slope. Geol. Soc. Am. Bull., 106:395-412.

Robb, J.M., Hampson, J.C., Jr., and Twichell, D.C., 1981. Geomorphology and sediment stability of a segment of the U.S. continental slope off New Jersey. Science, 211:935-937.

Sangrey, D.A., 1977. Marine geotechnology: state of the art. Mar. Geotechnol., Spec. Iss., 2:45-81.

Sills, G.C., Wheeler, S.J., Thomas, S.D., and Gardner, T.N., 1991. Behaviour of offshore soils containing gas bubbles. Geotechnique, 41:227-241.

Wheeler, S.J., 1990. Movement of large gas bubbles in unsaturated finegrained sediments. Mar. Geotechnol., 9:113-129.

Wheeler, S.J., Sham, W.K., and Thomas, S.D., 1989. Gas pressure in unsaturated offshore soils. Can. Geotech. J., 27:79-89.

Whelan, T., III, Coleman, J.M, Roberts, H.H., and Suhayda, J.N., 1976. The occurrence of methane in recent deltaic sediments and its effect on soil stability. 25th Int. Geol. Congr., Sydney, Australia.

Date of initial receipt: 13 March 1995

Date of acceptance: 27 July 1995

Ms 150SR-028 